\title{
A LIFE DEDICATED TO ROMANIAN LANGUAGE. INTERVIEW WITH 1 PROFESSOR ARNE HALVORSEN
}

\section{Crina Leon}

Alexandru Ioan Cuza University of Iaşi. E-mail: crina_laurentiu@yahoo.no

\section{Acknowledgements}

Supported by a grant from Iceland, Liechtenstein and Norway (Finanțat prin fonduri donate de Islanda, Liechtenstein şi Norvegia).

Professor Arne Halvorsen (1939-2014) was and remains a central figure when referring to Romanian-Norwegian cultural relations. In 2010 he was awarded the Order of Cultural Merit, in the rank of Commander, by the President of Romania, for his "exceptional contribution to promoting Romanian culture and language as well as Romania's image in the Kingdom of Norway". Due to his efforts, a Romanian language lectureship was established at the University of Trondheim (NTNU) in the period 2008-2011. Moreover, he wrote the first Romanian-Norwegian Dictionary (2001) and the first Romanian grammar in Norwegian (2012) - photos below.

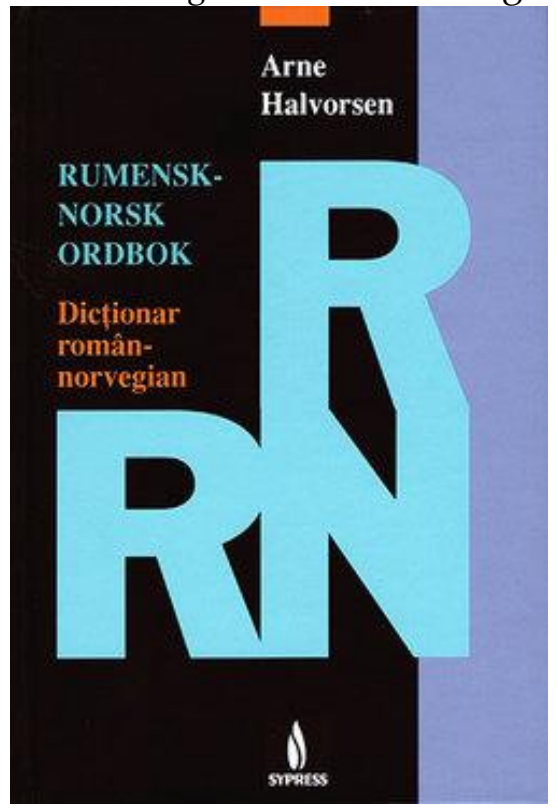

Arne Halvorsen

\section{Rumensk grammatikk}
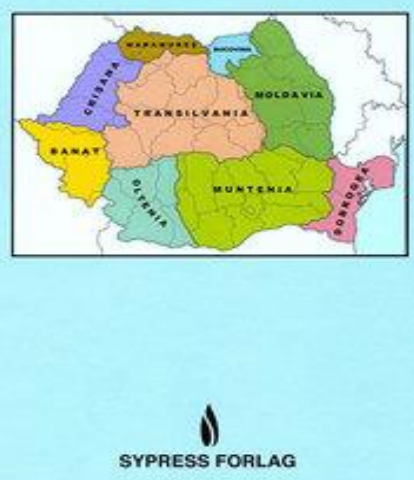
In what follows, we will publish a short interview taken with Professor Arne Halvorsen in October 2013.

Kan du fortelle oss hvordan du ble interessert i det rumenske språket? Could you tell us how you became interested in the Romanian language?

Det er en lengre historie, og som så ofte et resultat av tilfeldigheter. Men $i$ korte trekk: Jeg studerte eldre fransk da han som var professor i romanske språk, Leif Flydal, tilbragte sitt sabbatsår $i$ Bucureşti og hadde begynt å undervise i norsk der. Han mente at jeg burde dra ned og overta undervisningen. Etter å ha sett på kartet og funnet ut at Bucureşti var hovedstaden $i$ et land hoor de snakket et romansk språk, sa jeg ja. Etter et språkkurs $i$ Sinaia, dro jeg så til Bucureşti med rumensk statsstipendium. Med opphold var jeg der fra høsten 1967 til våren 1968. Rumensk syntes jeg var et vanskelig, men fascinerende språk. En heftig kjærlighetshistorie holdt nok også interessen vedlike!

It is a long story, and as it often happens the result of chance. But in brief: I was studying old French when the one who was a professor of Romance languages, Leif Flydal, spent his sabbatical year in Bucharest and began to teach Norwegian there. He thought that I should go and take over the teaching lessons. After I looked at the map and found out that Bucharest was the capital of a country where a Romance language was spoken, I said yes. After a language course in Sinaia, I went to Bucharest with a Romanian state scholarship. I stayed there from autumn 1967 to spring 1968. I thought that Romanian was a difficult, but fascinating language. A passionate love story probably maintained the interest as well!

\section{Hvordan prøvde du å fremme rumensk $i$ Norge? \\ How did you try to promote Romanian in Norway?}

Jeg har $i$ årene fra 1990 arbeidet for å innføre rumensk som universitetsfag. Det har vart en tung marsj mellom norsk utenriksdepartement og universitetene. Ifølge den interne arbeidsdeling mellom de norske universitetene skulle NTNU $i$ Trondheim fă rumensk. Problemet var bare at ingen hadde spurt om mitt universitet hadde penger til a finansiere et nytt fag. Som kjent ble faget innført først da rumenske myndigheter bevilget penger til en utenlandsklektor $i$ rumensk og den daværende rumenske konsul ga støtte til bolig.

In the years after 1990 I have worked to introduce Romanian as a university subject. It has been a difficult march between the Norwegian Ministry of Foreign Affairs and the universities. According to the internal division of labour between the Norwegian universities, NTNU1 in Trondheim should get Romanian. The problem was that no one had asked if my university had the money to finance a new subject. As it is known, the

\footnotetext{
${ }^{1}$ Norwegian University of Science and Technology
} 
subject was introduced only when the Romanian authorities granted money to a foreign Romanian lecturer and the Romanian consul at that time gave support for housing.

\section{Hvordan ser du norskens framtid i Romania?}

How do you see the future of Norwegian in Romania?

Norsk vil vel alltid vare et marginalt språk $i$ Romania, tross den store innsatsen fra mine svært så komptente kolleger $i$ Cluj og Iaşi. Romania har jo vist en større vilje og evne til å fremme små språkfag, så der ligger et håp.

Norwegian will probably always be a marginal language in Romania, despite the great efforts of my very competent colleagues in Cluj and Iaşi. Romania has shown a greater willingness and ability to promote small languages, so there is hope.

\section{Hva er din mening om rumensk litteratur?}

What is your opinion about Romanian literature?

Rumensk samtidslitteratur har jeg dessverre liten kjennskap til (stoppet ved Cărtărescu), men klassikerne hadde jeg stor glede av. Min favoritt var nok Caragiale og hans noveller. Planen var en gang å oversette dem til norsk, men som med mange planer ble det ikke noe av.

I have unfortunately little knowledge of contemporary Romanian literature, (stopped at Cărtărescu²), but I enjoyed a lot the classics. My favourite was probably Caragiale ${ }^{3}$ and his short stories. Once I was planning to translate them into Norwegian, but as in case of a lot of plans it did not come into fulfilment.

Siden du reiste til Romania for første gang (på 60-tallet), har mange ting forandret seg både i Romania og $i$ Norge. Hvordan betraktet du den tiden og hvordan betrakter du nåtiden $i$ disse to landene? Hva var forholdet mellom de to landene da og hvordan er det nå?

Since you first travelled to Romania (in the 60s), many things have changed both in Romania and in Norway. How did you look upon that time and how do you look upon the present time in these two countries? What was the relationship between the two countries then and how is it now?

\footnotetext{
2 Mircea Cărtărescu (born 1956) is a Romanian writer of prose, poetry and essays. His works which were translated from Romanian into Norwegian by Steinar Lone are: Travesti (Bokvennen, 1998), Nostalgia (Bokvennen, 2001), Blinding: The Left Wing (Bokvennen, 2008), Europe Has the Shape of My Brain (Gasspedal, 2008), Blinding: The Body (Bokvennen, 2010) and Blinding: The Right Wing (Bokvennen, 2011).

${ }^{3}$ Ion Luca Caragiale (1852-1912) was one of the greatest Romanian playwrights and short story writers.
} 
Romania i 1968 var en annen verden, nå har landet blitt svært mye likt vesteuropeiske land. Mitt møte med rumenske intellektuelle var en sjokkerende opplevelse for en lettere arrogant vest-europeer: kunnskapsnivået hos studenter og larere $i$ Bucureşti var imponerende. De hadde ikke bare inngående kjennskap til Norge og norske forhold (jeg husker en som ville vite hva jeg syntes om den norske komponisten Sinding), men kunne f. eks. en sen nattetime begynne å sitere gammelgreske tekster. Ellers var Bucureşti en nokså dyster by, grå om dagen, mørk om natten. Mine rumenske venner mente at nå gikk alt så mye bedre: det var mat å $f a ̊, o g$ det fantes utenlandsk litteratur å få kjøpt. Jeg syntes ikke det var mye å skryte av og reagerte negativt på at det faktum at min korrespondanse ble lest, og at mine venner måtte melde fra om kontakt med meg. Men vi var få vest-europeiske studenter og stipendiater i Bucureşti på den tiden (kanskje 10).

Det var heller ikke problemfritt å undervise i norsk der. Kopieringsmaskiner fantes ikke, og jeg måtte skrive av en lærebok jeg hadde med meg med mange blåkopier. Skrivemaskiner betraktet jo regimet som våpen (sant nok!), men jeg fikk låne maskinen som dekanus disponerte.

Forholdet mellom Romania og Norge har alltid vært fjernt, men vennlig. Det var en viss turisme til Svartehavet allerede i 60-årene. Men ellers var nok Romania et ukjent land for de fleste nordmenn. Turismen har nok stilnet, til gjengjeld fins det en del næringsvirksomhet som gjør at landene har oppdaget hverandre på en ny måte.

Romania was a different world in 1968, now the country has become very much like Western European countries. My encounter with Romanian intellectuals was a shocking experience for a slightly arrogant Western European: the level of knowledge among students and teachers in Bucharest was impressive. Not only did they have thorough knowledge about Norway and Norwegian relations (I remember someone wanting to know what I thought about the Norwegian composer Sinding 4 ), but could for example start quoting ancient Greek texts at late night hours. Otherwise Bucharest was a rather gloomy city, grey in the daytime, dark at night. My Romanian friends considered that now everything went so much better: there was food to get, and there was foreign literature to buy. I did not think there was much to write home about and reacted negatively to the fact that my correspondence was read and that my friends had to report any contact with me. But we were few Western European students and scholarship holders in Bucharest at that time (perhaps 10).

Neither was it unproblematic to teach Norwegian there. There were no photocopiers, and I had to copy a textbook I had with me by using many sheets of carbon paper. Typewriters were regarded as weapons by the

\footnotetext{
${ }^{4}$ Christian Sinding (1856-1941) was a Norwegian composer regarded as the successor of the most famous Norwegian composer Edvard Grieg (1843-1907).
} 
regime (true enough), but I could borrow the typewriter that the Dean possessed.

The relationship between Romania and Norway has always been distant, but friendly. There was some tourism to the Black Sea already in the 60s. But otherwise Romania was certainly an unknown country for most Norwegians. It seems that tourism has become less intensive; on the other hand there are some business activities that allow the countries to discover each other in a new way.

\section{Hva er din mening om stillingen Romania har i Europa nå?}

What is your opinion about the position Romania has now in Europe?

Etter min mening har Romania to hovedproblemer, som til en viss grad er knyttet sammen, nemlig en litt lite fundert demokratisk tradisjon og en utbredt korrupsjon på alle nivåer $i$ samfunnet. I mai 1990 var jeg valgoppservatør og opplevde det rene kaos i en landsby sør for Craiova. Folk var blitt narret til a tro at de ikke ville få jord hvis de ikke stemte og var rede til å tråkke hverandre ned for å få stemt. Mye har selvfølgelig endret seg siden da, men en skikkelig demokratisk holdning tar det tid å utvikle ( $i$ Norge har det tatt 200 år). Korrupsjonen $i$ Romania er gruoppvekkende og ødelegger forhold mellom mennesker. Forandringer er selvfølgelig et kollektivt ansvar, men holdningsendringer må utvikle seg hos hver og en av oss.

In my opinion, Romania has two major problems, which to some extent are linked together, namely a slightly less founded democratic tradition and a widespread corruption at all levels of society. In May 1990, I was an election observer and experienced pure chaos in a village south of Craiova. People had been fooled to believe that they would not receive land if they did not vote and were ready to trample one another so as to vote. Much has of course changed ever since, but it takes time to develop a proper democratic attitude (in Norway it has taken 200 years). Corruption in Romania is horrible and destroys the relationships between people. Changes are of course a collective responsibility, but attitude changes must evolve with each and every one of us.

På hvilken måte tror du at forholdene mellom Norge og Romania kan bli bedre i framtiden?

In which way do you think that the relations between Norway and Romania can be improved in the future?

Nøkkelordet er her utvidet kontakt, på alle områder.

The key word here is extended contact in all fields. 